\title{
Rola państwa w przeciwdziałaniu bezrobociu według encykliki Laborem exercens Jana Pawła II
}

Bezrobocie należy do najtrudniejszych kwestii społecznych w Polsce dwóch ostatnich dekad. Jest ono przedmiotem badawczym nauk ekonomicznych, społecznych i prawnych, znajduje się również w kręgu zainteresowań społecznej nauki Kościoła1. Szczególne znaczenie ma dla nas nauczanie Jana Pawła II, a w tym kontekście - przeprowadzona przez niego analiza problemu bezrobocia i walki z jego skutkami. Najbardziej pogłębione rozważania na ten temat zawarł Papież w encyklice Laborem exercens. Przeszło trzydzieści lat po jej opublikowaniu warto zauważyć, że mimo zmieniającej się sytuacji politycznej, gospodarczej i społecznej, nasilania się procesów globalizacji, zmian technologicznych, pojawiania się nowych trendów w gospodarce i sposobów zarządzania nadal zachowuje ona niezwykłą doniosłość i aktualność. Co więcej, w dobie wielkich problemów w światowej ekonomii, rozwijającego się kryzysu, braku stabilizacji i pewności rynkowej, wzrostu procesów migracji zarobkowych nauczanie Jana Pawła II zawarte w encyklice nabiera nowego wymiaru i znaczenia.

W encyklice Laborem exercens ${ }^{2}$ Papież dostrzega całą złożoność problemu bezrobocia. Wskazuje na przyczyny i skutki, dostrzega również potrzebę

" Dr Edyta Bıelak-JomaA, Katedra Prawa Pracy, Wydział Prawa i Administracji, Uniwersytet Łódzki, 90-232 Łódź, ul. Kopcińskiego 8/12.

1 Problematyka bezrobocia była podejmowana wielokrotnie zarówno w encyklikach papieskich - w encyklice Rerum novarum Leona XIII (1891), Laborem exercens (1981), Sollicitudo rei socjalis (1987) i Centesimus annus (1991) Jana Pawła II, a także w innych dokumentach Kościoła (np. Kościół i prawa człowieka, dokument Papieskiej Komisji lustitia et Pax z 10 grudnia 1974 r.; listy apostolskie Octogesima adveniens Pawła VI). Jan Paweł II wielokrotnie odnosił się do kwestii bezrobocia. Zob. przesłanie do uczestników konferencji na temat pracy, Rzym 14 września 2001 r., przemówienie podczas 68 Sesji MOP, Genewa 15 czerwca 1982 r., www.opoka.org.pl [dostęp: 16.10.2013].

2 JAN PAWEk II, Encyklika „Laborem exercens”. O pracy ludzkiej, Wrocław 1995, s. 37. Wszystkie odwołania opatrzone skrótem tytułu (LE) odnoszą się do tego wydania. 
przeciwdziałania temu zjawisku. Swoje rozważania na ten temat wiąże z prawem każdego człowieka do pracy, którą traktuje nie tylko jako powinność człowieka, lecz także jako dobro służące człowiekowi i przez niego wykorzystywane (LE, s. 37). W swoich rozważaniach podkreśla więc Jan Paweł Il ścisły związek między osobą ludzką a pracą - „przez pracę człowiek urzeczywistnia siebie jako człowiek” (LE, s. 33). Pozytywny, twórczy i wychowawczy charakter pracy ludzkiej pozwala na przyjęcie, że człowiek zawsze jest jej podmiotem (LE, s. 38). Praca stanowi obowiązek i prawo człowieka, jest również źródłem określonych uprawnień (LE, s. 58). Wśród nich na pierwsze miejsce wysuwa się prawo do pracy, traktowane jako pierwszorzędny warunek godnego życia i podstawowe dobro człowieka ${ }^{3}$.

O bezrobociu w świetle encykliki możemy mówić zarówno w sytuacji braku zatrudnienia w ogólności, jak i w przypadku braku zatrudnienia w poszczególnych sektorach pracy. „Szczególnie bolesny” jest problem bezrobocia ludzi młodych, którzy mimo zdobytego przygotowania zawodowego, technicznego i kulturalnego do pracy nie mogą znaleźć zatrudnienia (LE, s. 64). Nie mniej dotkliwy jest problem bezrobocia i proletaryzacji inteligencji, polegający na zaniżeniu zapotrzebowania na jej pracę. Bezrobocie wśród wykształconych ludzi powstaje albo wzrasta, gdy dostępne wykształcenie nie jest skierowane ku rodzajom prac czy usług, na jakie istnieje zapotrzebowanie na rynku. Innymi słowy, gdy nie ma związku między wykształconymi ludźmi a prawdziwymi potrzebami społeczeństwa, gdy praca specjalistyczna (do której wymagane jest określone wykształcenie) jest niżej opłacana niż praca fizyczna (LE, s. 30). Brak pracy jest przeciwieństwem odpowiedniego zatrudnienia, czyli właściwej i poprawnej sytuacji w zakresie polityki pracy, oznacza ono brak zatrudnienia dla uzdolnionych do tego podmiotów pracy (LE, s. 64).

Kluczowym zagadnieniem jest więc, w opinii Jana Pawła II, kwestia odpowiedniego zatrudnienia pracowników. Ponieważ bezrobocie, twierdzi Papież, jest zawsze złem, a w dużych rozmiarach może stać się klęską społeczną, należy mu przeciwdziałać. Zadanie przeciwdziałania bezrobociu należy przede wszystkim do państwa jako pracodawcy pośredniego. To państwo określa bowiem ustrój społeczno-ekonomiczny, powinno więc ustalać prawidłową, również z etycznego punktu widzenia, politykę pracy. Jednak, jak wskazuje Jan Paweł II w swoich rozważaniach, ciężar przeciwdziałania bezrobociu spoczywa na wszystkich instytucji krajowych i organizacjach międzynarodowych, odpowiedzialnych za całościowy kierunek polityki pracy. Właściwa polityka pracy powinna polegać na odpowiednim całościowym planowaniu, prawidłowej i celowej organizacji pracy. Nie chodzi jednak o realizowanie polityki sterowanej centralnie, niezbędna jest bowiem w tym zakresie trafna i celowa koordynacja działań poszczególnych ośrodków, osób, lokalnych warsztatów pracy. Państwo, określając kształt polityki w zakresie pracy, może precyzować postępowanie pracodawcy bezpośredniego, ponosi bowiem merytoryczną odpowiedzialność za kształt stosunków pracy - takich, w których

${ }^{3}$ M. DudA, Bezrobocie, [w:] Encyklopedia nauczania społecznego Jana Pawła II, red. A. Zwoliński, Radom 2003, s. 51. 
w pełni respektowane są obiektywne prawa człowieka. Państwo realizuje prawidłową politykę pracy również poprzez właściwy system kształcenia i wychowania, który zapewni rozwój dojrzałego człowieczeństwa oraz odpowiednie przygotowanie do zajęcia przy zróżnicowanym warsztacie pracy.

Jan Paweł II zwraca również uwagę na stałe dowartościowanie pracy ludzkiej, wychowywanie w przekonaniu, że praca jest dobrem jednostki i społeczeństwa. Dowartościowanie pracy ludzkiej następuje m.in. poprzez właściwe, godne jej wynagradzanie. Jej brak obciąża zatem nie tylko bezrobotnego, lecz także państwo - stąd troska o bezrobotnych i ich rodziny, przejawiająca się w postaci obowiązku wypłacania zasiłków niezbędnych do utrzymania bezrobotnych i ich rodzin.

Te działania państwo może podejmować przede wszystkim na płaszczyźnie wewnętrznej, krajowej. Jednak przeciwdziałanie bezrobociu jako zadanie państwa powinno być realizowane również w skali globalnej. W encyklice Jan Paweł II dostrzegł rolę współpracy międzynarodowej w zakresie przeciwdziałania bezrobociu, a szczególną rolę przypisał w tym zakresie Międzynarodowej Organizacji Pracy (LE, s. 63). Papież twierdzi, że na właściwą politykę pracy wpływa nie tylko ustrój społeczno-ekonomiczny, lecz także wzajemne powiązania między państwami. Postępująca globalizacja, rozwój form komunikowania się na odległość, fakt wzajemnego uzależnienia poszczególnych społeczeństw i państw oraz konieczność współpracy w różnych dziedzinach (przemysł, gospodarka, kultura) przemawia za tym, żeby - zachowując suwerenność państwową w zakresie polityki i organizacji pracy swojego społeczeństwa - prowadzić współpracę międzynarodową w formie porozumień między państwami, przedmiotem których będzie dążenie do wyrównywania poziomu życia poszczególnych społeczeństw. W przeciwnym razie bezpośredni pracodawcy znajdując się w systemie uwarunkowań globalnych, chcąc zachować konkurencyjność swoich usług czy towarów, mogą określać warunki pracy poniżej obiektywnych wymagań pracowników, co prowadzi do konfliktów i napięć społecznych. Rolą państwa powinno być zatem dążenie do kształtowania w drodze umów i porozumień międzynarodowych jak najlepszej sytuacji na rodzimym rynku pracy. Papież dostrzega niewystarczającą działalność wspólnot państwowych na tej płaszczyźnie. Wynikiem błędnej polityki międzynarodowej jest to, że, z jednej strony, istnieją niewykorzystane zasoby naturalne, z drugiej natomiast - całe rzesze bezrobotnych. Biorąc pod uwagę możliwości i uprawnienia państw, zarówno te wynikające z suwerenności (czyli prawo do kształtowania polityki wewnętrznej), jak i prawo do współdziałania przy kształtowaniu polityki międzynarodowej (poprzez udział w różnych organizacjach), państwa powinny prowadzić taką politykę, która ułatwi, umożliwi dostęp do pracy przy zagospodarowaniu zasobów natury poprzez zagospodarowanie bezrobotnych.

Przedstawiona w encyklice rola państwa w przeciwdziałaniu bezrobocia rodzi pytanie, czy taka koncepcja znajduje odzwierciedlenie w polskim systemie prawnym. Mając świadomość, że ograniczone ramy opracowania nie pozwalają odnieść się do wszystkich wskazanych w encyklice zagadnień związanych 
z rolą państwa w przeciwdziałaniu bezrobociu, rozważania swoje skupię tylko na niektórych prawnych rozwiązaniach w zakresie problemu przeciwdziałania bezrobociu. Uznając, za encykliką, że praca jest dobrem, zarówno dla człowieka, jak i dla społeczeństwa oraz państwa, w którym on żyje, należałoby przyjąć, że, po pierwsze, każdy ma do pracy prawo, po drugie zaś - w interesie państwa jest zapewnienie warunków wykonywania pracy zdolnym do niej ludziom. W polskich rozwiązaniach prawnych prawo do pracy nie zostało uwzględnione ani w Konstytucji RP ${ }^{4}$, ani w kodeksie pracy ${ }^{5}$. Można przyjąć, że odrzucenie formuły prawa do pracy w konstytucji i kodeksie pracy jest wynikiem poszanowania praw wolnorynkowych i własności prywatnej, a także rezygnacji z obowiązku państwa dostarczenia pracy wszystkim, bez względu na rzeczywiste możliwości i potrzeby rynku, to jednak jego nieuwzględnienie może wpływać na ocenę respektowania przez Polskę zobowiązań międzynarodowych w tym przedmiocie i osłabiać determinację państwa w walce z bezrobociem ${ }^{6}$. W przepisach konstytucji i kodeksu pracy brakuje elementu, jakim jest prawo obywatela do pomocy ze strony państwa w uzyskaniu zatrudnienia ${ }^{7}$. Lukę tę częściowo wypełnia akt wprost odnoszący się do kwestii bezrobocia - ustawa o promocji zatrudnienia i instytucjach rynku pracy ${ }^{8}$. Unormowania zawarte w przepisach tej ustawy są efektem wypełniania przez państwo zobowiązań wynikających z art. 65 ust 5 konstytucji, zgodnie z którym „władze publiczne prowadzą politykę zmierzającą do pełnego, produktywnego zatrudnienia poprzez realizowanie programów zwalczania bezrobocia [...]".

Prowadzenie polityki pełnego produktywnego zatrudnienia przez państwo nie oznacza jednak nakazu prawnego zapewnienia tego stanu, a raczej postulat podjęcia określonych kroków, które sprzyjają osiągnięciu i utrzymaniu jak najwyższego poziomu zatrudnienia, zwłaszcza że w systemie gospodarki wolnorynkowej i własności prywatnej jedynym dysponentem miejsca pracy jest niezależny pracodawca. Ustawa o promocji zatrudnienia wypełnia także zobowiązanie państwa określone w art. 67 ust. 2 konstytucji, zgodnie z którym obywatel pozostający bez pracy nie z własnej woli i nie mający innych środków utrzymania ma prawo do zabezpieczenia społecznego, którego zakres i formy określa ustawa. Chodzi zatem o stworzenie takiego systemu gwarancji państwa, w którym osoby bezrobotne będą

${ }^{4}$ Do zasady prawa do pracy odnosi się art. 65 ust. 1 Konstytucji RP, zgodnie z którym: „każdemu zapewnia się wolność wyboru i wykonywania zawodu oraz wyboru miejsca pracy". Konstytucja RP z dnia 2 kwietnia 1997 r., Dz. U. nr 78, poz. 483, ze zm.

${ }^{5}$ Art. 10 k.p. wprowadza zasadę prawa do swobodnie wybranej pracy oraz deklaruje, że państwo prowadzi politykę zmierzającą do pełnego produktywnego zatrudnienia; ustawa z dn. 26 czerwca 1974 r., Kodeks pracy, tekst jedn. Dz. U. 1998, nr 21, poz. 94, ze zm.

6 Z. Góral, Rola prawa w przeciwdziałaniu bezrobociu, [w:] Społeczne aspekty bezrobocia. Skutki i przeciwdziałanie, red. M. Seweryński, J. Wojtyła, Katowice 2002, s. 35-36.

7 J. Wratny, Prawo do pracy w czterech przybliżeniach: katolicka nauka społeczna, prawo międzynarodowe, prawo europejskie i prawo polskie, „Rynek Pracy” 2005, nr 7, s. 110.

8 Ustawa z dn. 20 kwietnia 2004 r. o promocji zatrudnienia i instytucjach rynku pracy, tekst jedn. Dz. U. 2008, nr 69, poz. 415, ze zm. (dalej: ustawa o promocji zatrudnienia). 
mogły liczyć na pomoc państwa w uzyskaniu pracy. Możemy więc mówić o prawie do pomocy w uzyskaniu zatrudnienia, rozumianym jako uprawnienie do skorzystania z mechanizmów prawnych, instytucji, urządzeń ułatwiających poszukiwanie pracy i podejmowanie zatrudnienia ${ }^{9}$. Osoba napotykająca w poszukiwaniu i podejmowaniu zatrudnienia na niezawinione przez siebie poważne trudności może liczyć na pomoc $w$ ich przezwyciężeniu ${ }^{10}$. Pomoc państwa w poszukiwaniu pracy nie może być jednak traktowana jako wyręczanie obywateli w ich staraniach o uzyskanie podstawowego źródła egzystencji. Państwo ma pomagać swym obywatelom stosownie do swoich możliwości i odpowiednio do rozwoju gospodarczego ${ }^{11}$.

Ustawa o promocji zatrudnienia i instytucjach rynku pracy $\mathrm{w}$ art. 1 określa zadania państwa w zakresie promowania zatrudnienia, łagodzenia skutków bezrobocia oraz aktywizacji zawodowej. Zadania państwa w tym zakresie można podzielić na kilka grup: zadania o charakterze polityczno-strategicznym (np. przygotowywanie i koordynacja planów działania na rzecz zatrudnienia, podział środków funduszu płac), organizacyjno-koordynacyjnym (np. organizowanie i koordynowanie usługami poradnictwa zawodowego i informacji zawodowej), operacyjnym (np. prowadzenie pośrednictwa pracy i poradnictwa zawodowego) oraz zadania wynikające z członkowska Polski w Unii Europejskiej ${ }^{12}$. Działania te tworzą politykę rynku pracy. Państwo powinno działać aktywnie na rzecz poprawy sytuacji na rynku pracy poprzez zapewnienie wzrostu gospodarczego, zwiększanie liczby miejsc pracy, ograniczanie rozmiarów i skutków bezrobocia. Efekty takich działań przekładają się na pomoc bezrobotnym w znalezieniu pracy, zabezpieczenie bytu socjalnego bezrobotnym, a także na ochronę miejsc pracy, ułatwienia i pomoc finansową oraz organizacyjną w ich tworzeniu. Zadania państwa w zakresie łagodzenia skutków bezrobocia są realizowane przez instytucje rynku pracy, które działają w celu pełnego i produktywnego zatrudnienia, rozwoju zasobów ludzkich, osiągnięcia wysokiej jakości pracy, wzmocnienia integracji oraz solidarności społecznej, zwiększania mobilności na rynku pracy.

Nie ulega wątpliwości, że najszerszy zakres obowiązków w związku z tymi celami spoczywa na państwie, ale skuteczna walka z bezrobociem wymaga zaangażowania także ze strony innych podmiotów ${ }^{13}$. Katalog podmiotów realizujących zadania rynku pracy obejmuje kategorię publicznych służb zatrudnienia (minister właściwy do spraw pracy, marszałek województwa, wojewoda, starosta wraz z urzędem obsługującym ministra, urzędy wojewódzkie, wojewódzkie urzędy pracy i PUP), Ochotnicze Hufce Pracy, agencje zatrudnienia, instytucje szkoleniowe, instytucje dialogu społecznego (organizacje związków zawodowych, organizacje

${ }^{9}$ Z. Góral, Prawo do pracy. Studium prawa polskiego w świetle porównawczym, Łódź 1994, s. $167-169$.

10 Ibidem, s. 164.

11 T. ZIELIŃSkI, Prawo do pracy - problem konstytucyjny, „Państwo i Prawo” 2003, nr 1, s. 9.

12 J. Stelina, Przegląd zadań państwa w zakresie promocji zatrudnienia, [w:] Rola prawa pracy i ubezpieczeń społecznych w przeciwdziałaniu bezrobociu, Gdańsk 2005, s. 80-81.

13 Z. Góral, Rola prawa..., s. 39. 
pracodawców, organizacje bezrobotnych i organizacje pozarządowe), instytucje partnerstwa lokalnego (grupa instytucji realizujących na podstawie umowy przedsięwzięcia i projekty na rzecz rynku pracy). Zadania państwa w zakresie polityki rynku pracy są zatem realizowane przede wszystkim przez publiczne służby zatrudnienia, ale mogą być zlecane również innym podmiotom o charakterze niepublicznym, na podstawie porozumień czy umów.

Ustawodawca wyposaża instytucje rynku pracy w określone instrumenty prawne, które mogą być stosowane w celu udzielania pomocy osobom bezrobotnym albo poszukującym pracy w jej podjęciu, zmianie czy zwiększeniu mobilności zawodowej. Pamiętać należy, że z usług i instrumentów rynku pracy służących aktywizacji zawodowej mogą korzystać w pełnym zakresie wyłącznie bezrobotni, a w wymiarze ograniczonym - poszukujący pracy, zarejestrowani w PUP. W przypadku bezrobotnych chodzi nie o wszystkie osoby pozostające bez pracy, lecz o te, które mają formalny status bezrobotnego ${ }^{14}$. Prawodawca zdecydował o możliwości udzielania bezrobotnym określonego wsparcia, którego celem jest podjęcie przez nich aktywności zawodowej. Dodać jednak należy, że nie chodzi o jakąkolwiek formę tej aktywności.

Podmioty świadczące usługi na rynku pracy udzielają pomocy w znalezieniu odpowiedniej pracy. Praca odpowiednia oznacza zatrudnienie lub inną pracę zarobkową, które podlegają ubezpieczeniom społecznym i do wykonywania których bezrobotny ma wystarczające kwalifikacje lub doświadczenie zawodowe lub może je wykonywać po uprzednim szkoleniu albo przygotowaniu zawodowym dorosłych, stan zdrowia pozwala mu na wykonywanie tej pracy. Ustawodawca wymaga również, do uznania danej pracy za odpowiednią, aby miejsce jej wykonywania było na tyle nieodległe od miejsca zamieszkania, żeby dojazd do pracy i z powrotem środkami transportu zbiorowego nie przekraczał 3 godzin. Wynagrodzenie z tytułu świadczenia pracy osiągać powinno co najmniej wysokość minimalnego wynagrodzenia za pracę ${ }^{15}$. Pojawia się pytanie, czy taka definicja odpowiedniej pracy pozwala na przyjęcie, że ustawodawca polski realizuje politykę pomocy bezrobotnym w znalezieniu pracy godziwej, której podjęcie nie będzie upokarzającą koniecznością dla bezrobotnego oraz czy dowartościowuje pracę i dostrzega podmiotową naturę zatrudnienia. Ponieważ $w$ definicji pracy odpowiedniej nie uwzględniono innych kryteriów: wieku, stażu pracy, doświadczenia, utraconych zarobków, sytuacji rodzinnej, aspiracji zawodowych, pozycji zawodowej, to w konsekwencji możliwe jest instrumentalne wykorzystanie tego

14 Definicja bezrobotnego zawarta w art. 2 ust. 1 pkt. 2 ustawy o promocji zatrudnienia jest bardzo rozbudowana i kazuistyczna. Wyodrębnia się w niej dwie części: w pierwszej określono przesłanki pozytywne - warunki, które muszą być spełnione, by można było uzyskać status bezrobotnego, w drugiej - przesłanki negatywne, a więc takie, które uniemożliwiają nabycie statusu mimo spełnienia przesłanek pozytywnych; por. Z. GóRAL, Komentarz do rozdziału I ustawy o promocji zatrudnienia i instytucji rynku pracy, [w:] Ustawa o promocji zatrudnienia i instytucjach rynku pracy. Praktyczny komentarz, red. Z. Góral, Warszawa 2011, s. 46.

15 Art. 2 ust. 1 pkt. 16 ustawy o promocji zatrudnienia. 
pojęcia i jego dostosowanie do sytuacji na rynku pracy. Jako że bezrobotny może w zasadzie tylko wyjątkowo odmówić przyjęcia propozycji pracy, służby zatrudnienia mogą właściwie proponować mu warunki pracy poniżej jego wykształcenia, kwalifikacji, doświadczenia zawodowego. To z kolei może prowadzić do degradacji społeczno-zawodowej bezrobotnych ${ }^{16}$.

Walka z bezrobociem jest możliwa poprzez kompleksowe działanie w sferze gospodarki w celu tworzenia nowych miejsc pracy i ochronę istniejących. Zadania te muszą być wspierane i uzupełniane w ramach polityki rynku pracy, służącej aktywizacji zawodowej bezrobotnych ${ }^{17}$. Ustawodawca wskazał w ustawie o promocji zatrudnienia kilka narzędzi aktywizacji bezrobotnych: usługi rynku pracy i wspierające te usługi instrumenty oraz programy specjalne, kierowane do osób wskazanych w art. 49a ustawy o promocji zatrudnienia. Odrębną kategorię pomocy stanowią zasiłki dla bezrobotnych.

Podstawowymi usługami rynku pracy są pośrednictwo pracy, poradnictwo zawodowe, informacja zawodowa, pomoc w aktywnym poszukiwaniu pracy i szkolenia. Instrumenty rynku pracy stanowią formę zachęty do korzystania z podstawowych usług i mają charakter pomocy finansowej, oferowanej podmiotom korzystającym z usług rynku pracy ${ }^{18}$. Dlatego instrumenty rynku pracy kierowane są do różnych podmiotów: bezrobotnych i poszukujących pracy, pracodawców i podmiotów prowadzących działalność gospodarczą. Pomoc kierowana do bezrobotnych zwiększa ich mobilność i polega na możliwości uzyskania zwrotu kosztów przejazdu do pracodawcy, który zgłosił ofertę pracy albo inną formę aktywizacji bezrobotnych, kosztów zakwaterowania w miejscu pracy oraz przyznanie środków na podjęcie działalności gospodarczej. Możliwość finansowania tych kosztów zależy od szeregu przesłanek, określonych w art. 45 oraz 46 ustawy o promocji zatrudnienia. Decyzja o przyznaniu środków ma charakter uznaniowy. Mimo więc spełnienia warunków bezrobotny może nie uzyskać takiej formy wsparcia w podjęciu aktywności zawodowej. Instrumenty rynku pracy mogą być kierowane także do pracodawców i podmiotów prowadzących działalność gospodarczą. Do tych instrumentów ustawodawca zaliczył możliwość dofinansowania wyposażenia miejsca pracy, refundowanie kosztów poniesionych z tytułu opłaconych składek na ubezpieczenie społeczne w związku z zatrudnieniem skierowanego bezrobotnego. Szereg instrumentów ustawodawca kieruje do grup osób szczególnie zagrożonych bezrobociem - m.in. niepełnosprawnych, osób młodych, długotrwale bezrobotnych, bezrobotnych po 50 roku życia, bezrobotnych samotnie wychowujących dzieci. Mobilność zawodową tych bezrobotnych zwiększają

${ }^{16}$ M. WŁodARCZYK, Odpowiednie zatrudnienie w ustawie o zatrudnieniu i przeciwdziałaniu bezrobociu, „Praca i Zabezpieczenie Społeczne” 1998, nr 7-8, s. 36; M. SzyLko-Skoczny, Polityka społeczna wobec bezrobocia w Trzeciej Rzeczypospolitej, Warszawa 2004, s. 154.

17 M. SzYLKo-SKoczNY, op. cit., s. 81.

18 T. WrockaWSKA, Komentarz do art. 44 ustawy o promocji zatrudnienia i instytucji rynku pracy, [w:] Ustawa o promocji zatrudnienia..., s. 291-292. 
dodatkowo instrumenty aktywizacji: prace interwencyjne, roboty publiczne, staże oraz niezwiązane bezpośrednio z pracą, ale ułatwiające jej podjęcie - zwrot kosztów opieki nad dzieckiem lub osobą zależną, które może uzyskać osoba samotnie wychowująca co najmniej jedno dziecko w wieku do 7 lat. Należy zauważyć i pozytywnie ocenić to, że ustawodawca dostrzega konieczność pomocy osobom zagrożonym marginalizacją społeczną. Większe ryzyko bezrobocia niektórych grup społecznych wymaga bardziej wyspecjalizowanej interwencji państwa w celu zwiększenia zatrudnienia. Istotną kwestią jest jednak zapewnienie efektywności tej pomocy, w razie zmian na rynku pracy szybkie jej modyfikowanie i wprowadzanie nowych rozwiązań odpowiadających konkretnym potrzebom pracodawców oraz umiejętnościom bezrobotnych.

Ustawodawca dostrzega również rolę wykształcenia jako środka w przeciwdziałaniu bezrobociu, które może być generowane lub ograniczane przez politykę edukacyjną. Polskie prawo uwzględnia potrzebę dostępu społeczeństwa do nauki jako drogę do jego rozwoju. Artykuł 70 Konstytucji RP zapewnia każdemu prawo do nauki, które oznacza dostęp do kształcenia się niezależnie od wieku, wykształcenia, miejsca zamieszkania itd. Szansa poprawy sytuacji na rynku pracy rośnie, gdy istnieje zapotrzebowanie na pracę świadczoną przez zdolnych i gotowych do jej podjęcia pracowników. W warunkach wolnorynkowych znaczenie ma przede wszystkim jakość pracy wykonywanej przez wysoko wykwalifikowane kadry. W tym kontekście bardzo ważne jest zagadnienie zależności między rynkiem pracy a edukacją. Prawidłowo zbudowany pomost nauki i gospodarki pozwala na adekwatne do potrzeb rynku zagospodarowanie wykształconych osób, wykwalifikowanych odpowiednio do potrzeb rynku i na rynku efektywnych. Oznacza to konieczność stałego wzrostu poziomu kwalifikacji, ich aktualizację i poszerzanie oraz dostosowywanie do zmieniających się potrzeb rynku i gospodarki; niezbędność wzrostu inwestycji w szkolnictwie, odpowiedniego wyposażenia i doposażenia szkół, zarówno zawodowych, jak i wyższych, podniesienie poziomu wykształcenia kadry nauczającej. Niezwykle istotne jest także inicjowanie współpracy między szkołami a pracodawcami, polegające np. na opracowaniu systemu zachęt dla pracodawców organizujących praktyki zawodowe ${ }^{19}$. W zakresie szkolnictwa wyższego postuluje się, aby państwo uruchomiło system regularnego i pogłębionego badania popytu na pracę, dokonywało kilkuletniego bilansu tego popytu i upowszechniało wyniki wśród wszystkich zainteresowanych ofertą edukacyjną podmiotów (młodzież, rodzice, szkoła). Ważne jest również stworzenie systemu powiązań między uczelniami, pracodawcami i związkami zawodowymi, co umożliwi doradztwo ze strony uczestników rynku pracy ${ }^{20}$.

19 M. ZaHORSKA, D. WalczAK, Polski system edukacyjny a rynki pracy w Unii Europejskiej, „Analizy i Opinie", październik 2005, nr 51, s. 8; tekst na stronie internetowej www.isp.org.pl [dostęp: 16.10.2013]; M. Gmytrasiewicz, M. Pastwa, Bezrobocie a edukacja, „Polityka Społeczna” 1991, nr 2, s. 5.

${ }^{20}$ M. ZAHORSKA, D. WALCZAK, op. cit., s. 9. 
Rolą polityki edukacyjnej jest stworzenie sytuacji, w której absolwenci różnych typów szkół będą mieli szansę na pracę zgodną ze zdobytymi kwalifikacjami. Jednak jak pokazuje sytuacja na rynku pracy, oferowane przez uczelnie wykształcenie coraz mniej odpowiada jego zmieniającym się wymogom. Problemem jest niedostosowanie kierunków kształcenia do potrzeb rynku pracy, zła jakość i niewłaściwa struktura kształcenia. Wybory maturzystów często są jednak podyktowane ofertą szkół. Zdecydowanie więcej jest miejsc na kierunkach humanistycznych, a nie inżynieryjno-technicznych. Podejmując decyzję o wyborze kierunku, abiturienci rzadko kierują się potrzebami pracodawców. W efekcie część z nich po ukończeniu nauki ma problem ze znalezieniem pracy i zasila szeregi bezrobotnych ${ }^{21}$. Absolwenci często nie mają praktycznych umiejętności ${ }^{22}$, wykazują się zbyt małą mobilnością i gotowością do przekwalifikowania ${ }^{23}$. Sposobem na silniejsze powiązanie gospodarki i edukacji może być program kierunków zamawianych ${ }^{24}$, możliwość podnoszenia kwalifikacji zawodowych pracowników ${ }^{25}$ i promocja kształcenia ustawicznego.

Prawo do podnoszenia ogólnej wiedzy lub swoich kwalifikacji zawodowych dotyczy wszystkich, w tym również bezrobotnych. W stosunku do tej grupy osób szczególne zasady podejmowania i odbywania szkoleń przewidział ustawodawca w ustawie o promocji zatrudnienia. W art. 40 tej ustawy określono adresatów oraz cel szkoleń. Zauważyć jednak trzeba, że szkolenie jest skierowane w szczególności do tych bezrobotnych, którzy nie mają żadnych kwalifikacji zawodowych, w stosunku do których istnieje konieczność zmiany lub uzupełnienia kwalifikacji, którzy utracili zdolność do wykonywania pracy w dotychczas wykonywanym zawodzie oraz tych, którzy nie potrafią aktywnie poszukiwać pracy ${ }^{26}$. Szkolenia bezrobotnych odgrywają istotną rolę w procesie powrotu do zatrudnienia. Biorąc pod uwagę, że stopień narażenia na ryzyko bezrobocia w coraz większym zakresie zależy od umiejętności szybkiego przekwalifikowania się, zdobycia nowej wiedzy i dostosowania jej do aktualnych wyzwań gospodarki, rośnie znaczenie programów pozwalających zdobyć, uzupełnić lub zmienić kwalifikacje zawodowe. Szkolenia ułatwiają powrót do aktywności zawodowej, spełniają dodatkowo

21 U. MiRowska, Maturzyści wybierając studia nie kierują się potrzebami pracodawców, „Gazeta Prawna", 16.03.2011, www.gazetaprawna.pl [dostęp: 16.10.2013]; W. Romańskı, Uczelnie i biznes muszą współpracować, „Rzeczpospolita”, 22.04.2011.

22 A. BŁaszczak, Po studiach prosto na bezrobocie, „Rzeczpospolita”, 10.03.2011.

${ }^{23}$ Młodzi są bezrobotni, bo mają nieodpowiednie wykształcenie, "Gazeta Prawna”, 7.01.2010; Studia nie gwarantują już pracy - co dziesiąty bezrobotny ma dyplom wyższej uczelni, „Gazeta Prawna", 18.02.2011.

${ }^{24} \mathrm{~J}$. WIŚNIEWSKI, Edukacja a rynek pracy w świetle reform edukacyjnych, „Praca i Zabezpieczenie Społeczne" 2010, nr 9, s. 4-5.

${ }^{25}$ Zgodnie $z$ art. $103^{1} \S 1$ k.p., przez podnoszenie kwalifikacji zawodowych rozumie się zdobywanie lub uzupełnianie wiedzy przez pracownika $z$ inicjatywy pracodawcy lub za jego zgodą.

${ }^{26}$ E. Bielak-JomaA, Komentarz do art. 40 ustawy o promocji zatrudnienia i instytucji rynku pracy, [w:] Ustawa o promocji zatrudnienia..., s. $270 \mathrm{i} \mathrm{n.}$ 
funkcję kształtowania właściwych postaw bezrobotnych, motywują do aktywnego poszukiwania pracy, umożliwiają kontakty społeczne ${ }^{27}$.

Wybór zawodu jest bardzo istotnym wydarzeniem w życiu człowieka, pozwala na zapewnienie materialnych podstaw egzystencji, daje także możliwość osiągnięcia satysfakcji zawodowej z wykonywanej pracy oraz zaspokaja osobiste aspiracje. Podjęcie niewłaściwej decyzji w tym zakresie może więc zwiększać ryzyko bezrobocia, a w konsekwencji skutkuje koniecznością zmiany dotychczas wykonywanego zawodu. Oznacza to w praktyce zaplanowanie kariery zawodowej i pokierowanie swoim losem. Państwo nie może być odpowiedzialne za indywidualne losy jednostki, jego rola sprowadza się do tworzenia instrumentów ułatwiających to zadanie ${ }^{28}$. Instytucją, której celem jest pomoc w wyborze zawodu i zatrudnienia, jest poradnictwo zawodowe, stanowiące integralną część informacji zawodowej ${ }^{29}$. Poradnictwo zawodowe i informacja zawodowa mają dostarczać tym, którzy szukają zatrudnienia po raz kolejny lub pierwszy raz w życiu, jak najpełniejszej informacji, uwzględniających aktualną sytuację na rynku pracy ${ }^{30}$. Poradnictwo zawodowe prowadzone przez powiatowe urzędy pracy opiera się na systemie informacji i orientacji zawodowej. Informacja zawodowa jest źródłem wiedzy o sytuacji na rynku pracy, szansach znalezienia zatrudnienia, możliwościach szkolenia i przekwalifikowania zawodowego. Orientacja zawodowa polega natomiast na podejmowaniu działań mających na celu zasugerowanie trafnego wyboru zatrudnienia ${ }^{31}$. Ten instrument walki z bezrobociem jest, według mnie, bardzo istotnym narzędziem pomocy bezrobotnym podczas dokonywania wyboru zawodu lub możliwości szkolenia. Prawidłowo zastosowany pozawala wyzwolić inicjatywę w poszukiwaniu pracy, ułatwia działanie na rynku, motywuje bezrobotnych do podejmowania różnego rodzaju aktywności zawodowej.

Nie zawsze pomoc w znalezieniu zatrudnienia, podjęciu innej formy aktywności zawodowej, zwiększeniu mobilności zawodowej może zostać zrealizowana. W takiej sytuacji powstaje potrzeba zabezpieczenia egzystencji osób, które znalazły się z niezawinionych przez siebie przyczyn poza zatrudnieniem. Taką rolę pełni przede wszystkim zasiłek dla bezrobotnych. Jednak prawo do niego powstaje dopiero w razie braku możliwości skorzystania ze środków mających na celu podjęcie przez bezrobotnego pracy ${ }^{32}$. Zasiłek ma na celu zapewnienie minimalnego

27 M. SzYLKo-SKoczny, op. cit., s. 205.

28 E. Staszewska, Komentarz do art. 38 ustawy o promocji zatrudnienia i instytucji rynku pracy, [w:] Ustawa o promocji zatrudnienia..., s. 255.

${ }_{29}$ Zgodnie z art. 38 ustawy o promocji zatrudnienia, poradnictwo zawodowe i informacja zawodowa polega na oferowanej bezrobotnym i poszukującym pracy pomocy w wyborze odpowiedniego zawodu i miejsca zatrudnienia oraz pracodawcom w doborze kandydatów do pracy i udzielaniu porad zawodowych służących wspieraniu rozwoju zawodowego pracodawcy i jego pracowników.

30 E. StASZEWSKA, op. cit., s. 255.

31 M. SzYLKo-SKoczNY, op. cit., s. 202-203.

32 Wyrok Wojewódzkiego Sądu Administracyjnego w Warszawie z dn.14 czerwca 2006 r., II SA/ Wa 463/06, LEX nr 221873. 
dochodu, jednocześnie ma motywować do poszukiwania pracy ${ }^{33}$. Jego uzyskanie jest uzależnione od spełnienia określonych przesłanek. Prawo do zasiłku uzależnione jest od posiadania statusu bezrobotnego i powstaje w przypadku braku propozycji odpowiedniej pracy oraz legitymowania się przez bezrobotnego odpowiednim stażem - okresem zatrudnienia, innej aktywności zawodowej lub okresem z nim zrównanym (okres co najmniej 365 dni przypadających w czasie 18 miesięcy poprzedzających dzień zarejestrowania w charakterze bezrobotnego) oraz osiąganiu $z$ tego tytułu dochodu w wysokości co najmniej minimalnego wynagrodzenia za pracę ${ }^{34}$.

Zasiłek nie jest jednak jedyną formą ochrony socjalnej bezrobotnych. Wspierają ich także inne świadczenia urzędów pracy, wśród których można wymienić: dodatki aktywizacyjne ${ }^{35}$, stypendia ${ }^{36}$, zasiłki przedemerytalne, świadczenia przedemerytalne ${ }^{37}$, świadczenia przysługujące osobie wykonującej pracę na podstawie skierowania starosty. Oprócz wymienionych świadczeń ustawa przewiduje szereg innych form finansowego wsparcia bezrobotnych: zwrot kosztów przejazdu do miejsca pracy w związku ze skierowaniem bezrobotnego do pracy przez starostę, zwrot kosztów zakwaterowania w związku z takim skierowaniem, refundowanie kosztów opieki nad dzieckiem i osobą zależną, możliwość uzyskania nieoprocentowanej pożyczki szkoleniowej ${ }^{38}$, kosztów studiów podyplomowych, udzielanie środków na podjęcie działalności gospodarczej przez bezrobotnych ${ }^{39}$. Warto wspomnieć o świadczeniach z pomocy społecznej, do których uprawnieni są bezrobotni ${ }^{40}$. Wśród różnych świadczeń pieniężnych, bezrobotni mają prawo do zasiłków okresowych oraz zasiłków celowych. Zasiłek okresowy jest przyznawany bezrobotnym, jeżeli spełniają kryteria udzielenia pomocy (wśród nich - kryterium dochodu) na okres, o długości którego decyduje pracownik socjalny po analizie wszystkich okoliczności ${ }^{41}$. Zasiłek celowy przyznawany jest na zaspokojenie niezbędnej potrzeby bytowej (zakup lekarstw, opału, odzieży ${ }^{42}$. Zadaniem pomocy społecznej jest, $z$ jednej strony, zaspokojenie niezbędnych potrzeb bytowych bezrobotnego i jego rodziny, z drugiej zaś - określenie takiej wielkości pomocy, aby nie wystąpił u wspomaganej osoby syndrom uzależnienia się od niej. Świadczenia z pomocy społecznej powinny więc sprzyjać aktywności zawodowej i społecznej podopiecznych oraz motywować ich do podejmowania zatrudnienia ${ }^{43}$.

${ }^{33}$ M. SZYLKo-SKoczNy, op. cit., s. 148.

${ }^{34}$ Z. Góral, Komentarz..., s. 448 i n.

${ }^{35}$ Art. 48 ustawy o promocji zatrudnienia.

${ }^{36}$ Art. 41, 42a, 53, 53g, 55 ustawy o promocji zatrudnienia.

${ }^{37}$ Art. 141 ustawy o promocji zatrudnienia.

${ }^{38}$ Art. 42 ustawy o promocji zatrudnienia.

39 Art. 46 ustawy o promocji zatrudnienia.

40 Art. 7 ustawy z dnia 12 marca 2004 r. o pomocy społecznej, tekst jedn. Dz. U. 2009, nr 175, poz. 1362, ze zm., zwana dalej ustawą p.s.

41 Art. 38 ustawy p.s.

${ }^{42}$ Art. 39 ustawy p.s.

${ }^{43}$ M. SzyLko-Skoczny, op. cit., s. 169. 
Poza ochroną socjalną, realizowaną głównie w formie świadczeń o charakterze materialnym, które zabezpieczają egzystencję bezrobotnych, istotną rolę ogrywać może pomoc niematerialna świadczona na ich rzecz. Powinna być realizowana w formie porad prawnych, psychologicznych, metod rozwoju osobowościowego, doradztwie zawodowym ${ }^{44}$ i świadczona zarówno podczas korzystania z pośrednictwa pracy (w świetle art. 36 ust. 1 pkt 7 pośrednictwo pracy polega m.in. na informowaniu bezrobotnych o przysługujących im prawach i obowiązkach), poradnictwa zawodowego lub w ramach pomocy w aktywnym poszukiwaniu pracy ${ }^{45}$.

Wachlarz pomocy finansowej świadczonej na rzecz bezrobotnych jest stosunkowo szeroki. Nie oznacza to jednak, moim zdaniem, że stworzenie możliwości pomocy materialnej jest równoznaczne z zabezpieczeniem bytu socjalnego bezrobotnych. W tym kontekście należy pamiętać o dostępności świadczeń, procedurze ich przyznawania oraz wysokości. Ustawodawca przewidział możliwość zastosowania tych instrumentów pomocy, pozostawiając staroście decyzję o ich skierowaniu do konkretnego bezrobotnego. Poza tym o efektywności każdej z form decyduje sposób jej wykorzystywania. Na skuteczność składa się wiele czynników: uwarunkowania gospodarcze, poziom rozwoju parku technologicznego i technicznego danego regionu, ale również warunki demograficzne, geograficzne, zaplecze naukowe i badawcze oraz sytuacja osobista i przymioty samego bezrobotnego.

Powyższe rozważania w żaden sposób nie wyczerpały wszystkich wątków z zakresu prezentowanej tematyki. Takie istotne zagadnienia, jak choćby problem współpracy międzynarodowej w zakresie działań na rzecz walki z bezrobociem czy wpływ i skutki globalizacji na bezrobocie zasługują, ze względu na swój specyficzny charakter, na odrębne opracowanie. Oceniając polskie rozwiązania odnoszące się do przeciwdziałania bezrobociu, trzeba dostrzec wysiłki ustawodawcy w tym kierunku. Skuteczność tych działań jest ciągle niedostateczna, o czym świadczy masowy i trwały, a ostatnio nasilający się charakter bezrobocia ${ }^{46}$. Ta problematyka należy do niezwykle trudnych sfer działania. Mamy tu do czynienia z przenikaniem się gospodarki, finansów, techniki, kultury, polityki, prawa. Walka z bezrobociem wymaga kompleksowego, długofalowego działania i zaangażowania wszystkich podmiotów zainteresowanych poprawą sytuacji na rynku pracy

${ }^{44}$ W art. 46 ust 1 pkt. 2 ustawy o promocji zatrudnienia przewidziano np. możliwość przyznania środków finansowych bezrobotnemu na pokrycie kosztów pomocy prawnej, konsultacji i doradztwa związanych z podjęciem działalności.

45 Pomoc w aktywnym poszukiwaniu pracy polega na przygotowaniu bezrobotnych do lepszego radzenia sobie w poszukiwaniu i podejmowaniu zatrudnienia, w szczególności przez: uczestnictwa w szkoleniu z zakresu umiejętności poszukiwania pracy czy w zajęciach aktywizacyjnych (art. 39 ustawy o promocji zatrudnienia).

46 W marcu 2013 r. bezrobocie w Polsce wynosiło 14,3\% (2 314 500) i poziom ten wzrósł w porównaniu z analogicznym okresem poprzedniego roku o 1,0 punkt procentowy, a w porównaniu z listopadem 2011 r. - 12,1\% (1 914936 osób); dane dostępne na stronie GUS, www.stat. gov.pl/GUS [dostęp: 16.10.2013]. 
oraz różnych środków i metod ${ }^{47}$. Aktywność państwa na rynku pracy powinna mieć charakter makroekonomiczny, czyli taki, w którym wykorzystuje się instrumenty polityki budżetowej, pieniężnej, współpracy gospodarczej z zagranicą ${ }^{48}$. Kompleksowa reforma rynku pracy musi brać pod uwagę to, że w gospodarce będą się pojawiać kryzysy ekonomiczne, rozwijać nowe technologie, pozwalające zastępować człowieka w procesie pracy, nowe modele organizacji pracy, a potrzeby człowieka i jego oczekiwania - m.in. dotyczące aspiracji zawodowych - nie będą maleć. Dlatego konieczna jest umiejętność spojrzenia na wewnętrzny rynek pracy przez pryzmat procesów globalnych, poszukiwanie rozwiązań, które mogłyby znaleźć zastosowanie w różnych warunkach ekonomicznych i społecznych. Pamiętać bowiem należy, że „człowiek nie może być widziany jako narzędzie produkcji. Człowiek jest twórcą pracy i jej sprawcą. Trzeba uczynić wszystko, aby praca nie straciła swojej właściwej godności"49.

47 G. ORŁowski, Kilka uwag o walce z bezrobociem i innymi problemami rynku pracy, „Monitor Prawa Pracy" 2011, nr 11, s. 564.

${ }^{48}$ E. KRYNSKA, Z. WiśnIEWSKI, Trzynaście tez w sprawie reformy polityki państwa na rynku pracy w Polsce, „Polityka Społeczna” 2007, nr 9, s. 1.

49 Homilia Jana Pawła II podczas Mszy Św. na Lednickim Polu, Lednica, 2 czerwca 1997 r., www.opoka.gov.pl [dostęp: 16.10.2013]. 